\title{
WPEYW BMI NA STABILNOŚĆ POSTURALNĄ KOBIET W OKRESIE WCZESNEJ STAROŚCI
}

\section{THE INFLUENCE OF BMI ON POSTURAL STABILITY OF WOMEN IN THE PERIOD OF EARLY OLD AGE}

\author{
Grażyna Olchowik ${ }^{1(\mathrm{~A}, \mathrm{D}, \mathrm{E})}$, Marek Tomaszewski $\mathbf{i}^{2(\mathrm{D}, \mathrm{E}, \mathrm{F})}$, \\ Agata Czwalik $^{1(\mathrm{~B}, \mathrm{C}, \mathrm{F})}$, Monika Tomaszewska ${ }^{3(\mathrm{D}, \mathrm{F})}$ \\ ${ }^{1}$ Katedra i Zakład Biofizyki Uniwersytetu Medycznego w Lublinie \\ ${ }^{2}$ Katedra i Zakład Anatomii Prawidłowej Człowieka Uniwersytetu Medycznego w Lublinie \\ ${ }^{3}$ I Zakład Radiologii Lekarskiej Uniwersytetu Medycznego w Lublinie
}

Olchowik, G., Tomaszewski, M., Czwalik, A., Tomaszewska, M. (2018). Wpływ BMI na stabilność posturalną kobiet w okresie wczesnej starości. Rozprawy Społeczne, 12(4), 81-86. https://doi.org/10.29316/rs.2018.40

Wkład autorów:

A. Zaplanowanie badań

B. Zebranie danych

C. Dane - analiza i statystyki

D. Interpretacja danych

E. Przygotowanie artykułu

F. Wyszukiwanie i analiza

literatury

G. Zebranie funduszy
Tabele: 1

Ryciny: 3

Literatura: 24

Otrzymano: czerwiec 2018

Zaakceptowano: sierpień 2018

\begin{abstract}
Streszczenie
Wstęp. W pracy dokonano ilościowej analizy wpływu wskaźnika BMI na stabilność posturalną kobiet w okresie wczesnej starości.

Materiał i metody. Badania przeprowadzono w grupie 41 kobiet w wieku 60-74 lata. Stabilność posturalną kobiet oceniano za pomocą komputerowej dynamicznej posturografii (CDP). Oceniano użyteczność sygnałów pochodzących z narządów zmysłów biorących udział w kontroli równowagi ciała oraz prawidłowość doboru odpowiedniej strategii motorycznej. Określano wychylenia środka ciężkości ciała w kierunku przednio-tylnym i łączny wynik analizy równowagi ciała. Wyniki. W wyniku przeprowadzonych badań stwierdzono ujemna korelacje wskaźnika BMI badanych kobiet z wynikami analizy równowagi oraz wynikami analizy strategii motorycznej.

Wnioski. Wraz ze wzrastającą wartością wskaźnika BMI zwiększa się zakres wychwiań środka ciężkości kobiet w kierunku przednio-tylnym. U osób z nadwagą stwierdzono gorsze wykorzystanie informacji somatosensorycznych i strategię stawu biodrowego. Otrzymane ilościowe zależności pomiędzy parametrami układu równowagi ciała ocenianymi w badaniu CDP a BMI wskazują na niekorzystny wpływ nadwagi i otyłości na stabilność posturalną kobiet w okresie wczesnej starości.
\end{abstract}

Słowa kluczowe: masa ciała, BMI, stabilność posturalna

\section{Summary}

Introduction. In this study, a quantitative analysis of the BMI index on the postural stability of women in early old age was conducted.

Materials and methods. The study was conducted in a group of 41 women aged 60-74. The postural stability of women was assessed using computerized dynamic posturography (CDP). The usefulness of signals coming from sensory organs involved in the control of the body's balance and the correctness of choosing the appropriate motor strategy were assessed. The deflections of the centre of gravity of the body in the anteroposterior direction and the combined result of body balance analysis were determined.

Results. As a result of the conducted research, a negative correlation between the BMI index of the studied women and the results of the balance analysis, as well as the results of the motor strategy analysis was found.

Conclusions. Along with the increase in the BMI index, there increases the range of deflections of women's centre of gravity in the anteroposterior direction. In overweight people, worse use of somatosensory information and hip joint strategy was found. The obtained quantitative relationships between the parameters of the body balance system assessed in the CDP examination and BMI indicate the adverse effect of excessive weight and obesity on the postural stability of women in early old age.

Keywords: body mass, BMI, postural stability

Adres korespondencyjny: Grażyna Olchowik, Katedra i Zakład Biofizyki Uniwersytetu Medycznego w Lublinie, 20-090 Lublin, ul Jaczewskiego 4, e-mail: grazyna.olchowik@umlub.pl, tel.: 604565405; ORCID: https://orcid.org/0000-0002-5599-3818 Tomaszewska

Czasopismo Open Access, wszystkie artykuły udostępniane są na mocy licencji Creative Commons Uznanie autorstwa-użycie niekomercyjne-na tych samych warunkach 4.0 Międzynarodowe (CC BY-NC-SA 4.0, http://creativecommons.org/licenses/by-nc-sa/4.0/). 


\section{Wstęp}

Wzrost średniej długości życia oraz niski przyrost naturalny większości społeczeństw krajów rozwiniętych gospodarczo powodują gwałtowne starzenie się społeczeństwa. Bardzo poważnym problemem zarówno geriatrycznym, społecznym jak i ekonomicznym, związanym z procesem starzenia się człowieka jest wzrost ryzyka upadków. Upadki stanowią zagrożenie dla zdrowia i życia i są konsekwencją zaburzeń czynności układu równowagi ciała. Częstość występowania zaburzeń czynności układu równowagi ciała człowieka wzrasta z wiekiem, co wynika z postępującego zwyrodnienia wszystkich układów czynnościowych i anatomicznych, od wydolności których zależy stabilność postawy (Błaszczyk, Czerwosz, 2005). Niestabilność posturalna u osób starszych spowodowana może być upośledzeniem któregokolwiek z komponentów biorących udział w kontroli równowagi ciała. Procesy inwolucyjne związane z pogorszeniem stabilności to przede wszystkim spowolnienie reakcji ruchowych związane ze spadkiem średniej szybkości przewodzenia impulsów nerwowych, utrata masy mięśniowej, zanik receptorów narządów kontrolujących równowagę oraz spadek ostrości widzenia (Janczewski, Pierchała, 2003; Janssen, 2010; Wiszomirska i in., 2013). Czynniki te powodują stopniowe zmniejszanie obszaru stabilności postawy stojącej, czego skutkiem jest wzrost ryzyka upadków osób starszych. Upadki w grupie seniorów wiążą się z wieloma poważnymi konsekwencjami i częściej niż w przypadku innych grup wiekowych są przyczyną śmierci, niepełnosprawności, złamań i lęku przed kolejnym upadkiem, powodując znaczne obniżenie jakości życia tych osób (Błaszczyk, Lowe, Hansen, 1994; Borzym, 2009). Według autorów pracy (Edbom-Kolarz, Marcinkowski, 2011) aż 30\% osób po 65 roku życia narażonych jest na upadek przynajmniej raz w ciaggu roku, a aż $50 \%$ upadków kończy się urazem prowadzącym do hospitalizacji, znacznego ograniczenia sprawności fizycznej, a nawet śmierci. Ryzyko upadku zakończonego śmiercią w grupie osób powyżej 65 roku życia jest siedmiokrotnie wyższe niż u osób młodych, a 5 - 15\% upadków powoduje złamania, zwichnięcia oraz poważne urazy głowy i uszkodzenia tkanek miękkich (Błaszczyk, Czerwosz, 2005). Problemu nie stanowi sam fakt upadania, lecz konsekwencje upadków, uniemożliwiające dotychczasowy tryb życia seniorów i prowadzący do obniżenia jakości życia. Dlatego też tak ważne jest ustalenie wszelkich podlegających ewentualnym modyfikacjom czynników, mogących dodatkowo pogarszać stan funkcjonowania układu równowagi seniorów.

Zadania jakim musi sprostać układ równowagi to informowanie o aktualnym położeniu ciała i jego ewentualnym ruchu w przestrzeni, szybka reakcja zapobiegająca upadkowi oraz kontrola położenia gałek ocznych w celu utrzymania stabilnego obrazu otoczenia. Ponieważ $w$ ciele człowieka nie istnieje jeden wyspecjalizowany organ kontrolujący położenie środka ciężkości, informacje o jego położeniu ciało człowieka rejestruje na podstawie danych z narządu wzroku, narządu przedsionkowego i proprioreceptorów układu czucia głębokiego (Błaszczyk, 2004; Held-Ziółkowska, 2006b). Wyznacznikiem stabilności postawy jest położenie rzutu środka ciężkości ciała wewnątrz pola podparcia, które w pozycji stojącej stanowi obrys stóp (Horak, 2006). Głównym parametrem kontrolowanym podczas badań posturograficznych jest właśnie położenie i prędkość wychwiań rzutu środka ciężkości na płaszczyzne postawy. W ocenie jakości kontroli posturalnej pod uwagę brane są także: użyteczność poszczególnych narządów zmysłu biorących udział w kontroli posturalnej i prawidłowość doboru odpowiedniej strategii motorycznej.

Celem pracy było ustalenie wpływu wartości wskaźnika BMI na jakość kontroli równowagi kobiet w okresie wczesnej starości.

\section{Materiał i metody}

Badania przeprowadzone zostały w Katedrze i Zakładzie Biofizyki Uniwersytetu Medycznego w Lublinie za zgodą Komisji Bioetycznej. Badaniami objęto grupę 41 kobiet w wieku 60 - 74 lata, zdefiniowanym w 2015 roku przez światową Organizację Zdrowia (WHO) jako wczesna starość. Badania zostały przeprowadzone $\mathrm{w}$ jednorodnej grupie pod względem płci zgodnie z zaleceniami pracy (Olchowik, 2015). Na grupę badaną wybrano osoby po 60tym roku życia, ponieważ zachodzące w układzie równowagi zmiany uwidaczniają się w tym okresie życia człowieka.

Badane kobiety zostały wyłonione z grupy liczącej 72 osób w oparciu o kwestionariusz oceny stanu zdrowia. Z badań wykluczano osoby, których odpowiedzi wskazywały na posiadane wady postawy, bezsenność, wysteppowanie zawrotów głowy i zaburzeń równowagi, niedosłuch, doskwierające szumy uszne lub wielokrotnie przebyte zapalenia uszu, a także osoby, które w przeszłości doświadczyły poważnego urazu głowy lub kręgosłupa. Wykluczone zostały także osoby leczone $\mathrm{z}$ powodu chorób przewlekłych oraz przyjmujące w okresie ostatniego miesiąca leki mogące upośledzać funkcjonowanie układu równowagi. Charakterystykę grupy badanej umieszczono $\mathrm{w}$ tabeli 1 .

Tabela 1. Charakterystyka grupy badanych kobiet $(n=41)$ pod względem wieku, wysokości i masy ciała oraz wskaźnika BMI. W tabeli podano wartości średnie i odchylenie standardowe

\begin{tabular}{|c|c|c|}
\hline \multirow{2}{*}{ Parametr } & \multicolumn{2}{|c|}{ Seniorki (n=41) } \\
\cline { 2 - 3 } & M & SD \\
\hline Wiek [lat] & 66,2 & 4,5 \\
\hline Wysokość t [cm] & 160,1 & 5,3 \\
\hline Waga [kg] & 66,7 & 6,3 \\
\hline BMI [kg/m $\left.{ }^{2}\right]$ & 27,1 & 3,2 \\
\hline
\end{tabular}


W celu zbadania zależności pomiędzy wskaźnikiem BMI a jakością utrzymywania równowagi, zmierzono wysokość osób badanych, masę ciała, a następnie przeprowadzono badanie posturograficzne. Wskaźnik BMI określono jako iloraz masy ciała i kwadratu wysokości ciała.

Badanie posturograficzne przeprowadzone zostało $\mathrm{z}$ wykorzystaniem posturografu dynamicznego EquiTest firmy NeuroCom International. Protokół badania obejmował test organizacji zmysłowej (SOT). Test ten pozwala ocenić użyteczność sygnałów pochodzących z poszczególnych zmysłów biorących udział w kontroli równowagi ciała oraz prawidłowość doboru odpowiedniej strategii motorycznej. Test ten przeprowadzany jest w sześciu warunkach, podczas których zmianom podlegają bodźce wzrokowe, wprowadzany jest ruch rotacyjny platformy stanowiącej płaszczyznę podparcia stóp, lub też ruch przesłony stanowiącej otoczenie wzrokowe. Podczas trzech pierwszych prób powierzchnia podparcia jest ustalona, a zmienne są informacje docierające do narządu wzroku (oczy otwarte, nieruchome otoczenie wzrokowe - SOT1, oczy zamknięte - SOT2, oczy otwarte, ruchome otoczenie wzrokowe - SOT3). Na podstawie analizy stabilności postawy w trakcie tych prób, oceniania jest użyteczność sygnału z narządu somatosensorycznego (SOM) oraz narządu wzroku (VIS). Kolejne trzy próby odbywają się przy ruchomej płaszczyźnie podparcia, zakłócając informacje otrzymywane poprzez układ czucia głębokiego oraz tak jak w przypadku poprzednich prób, kolejno zmieniane są informacje wzrokowe (oczy otwarte - SOT4, oczy zamknięte - SOT5, ruchome otoczenie wzrokowe - SOT6). Dwie ostatnie próby pozwalają na ocenę użyteczności narządu przedsionkowego (VEST), którego rola znacząco rośnie w przypadku niewłaściwych lub wyłączonych informacji pochodzących z pozostałych narządów biorących udział w kontroli postawy ciała. Ocenie podlega także zdolność pacjenta do tłumienia sprzecznych z rzeczywistością bodźców wzrokowych (PREF). Wyniki te świadczą o uży teczności sygnału $\mathrm{z}$ danego układu sensorycznego w kontroli równowagi ciała. Są one prezentowane w skali procentowej. Wartość 100\% oznacza pełną sprawność danego użyteczności poszczególnego układu sensorycznego i prawidłowe wykorzystywanie sygnału z tego układu w kontroli równowagi ciała.

Oprócz funkcjonalności poszczególnych narządów zmysłów (SRS), podczas testu SOT określane są również wychylenia środka ciężkości ciała w kierunku przednio-tylnym (ES) i prawidłowość doboru odpowiedniej strategii ruchowej (MS) (Held -Ziółkowska, 2006a). Wynik analizy równowagi ciała (ES) umożliwia ilościową ocenę odchyleń środka ciężkości ciała w kierunku przednio-tylnym. Wynik równy $100 \%$ oznacza brak odchyleń środka ciężkości ciała w kierunku przednio-tylnym. Im większy jest zakres tych odchyleń tym mniejszą wartość przyjmuje wynik analizy równowagi ciała.
Łączny wynik analizy równowagi ciała (CES) uwzględnia odchylenia środka ciężkości ciała podczas wszystkich prób testu organizacji zmysłowej. Wartość CES jest średnią ważoną wartości ES z sześciu warunków stymulacji narządów zmysłów (Olejarz, Olchowik, 2011).

Wynik analizy strategii motorycznej (MS) umożliwia ilościową ocenę aktywności mięśniowej odpowiedzialnej za ruchy w stawach skokowych oraz aktywności mięśniowej odpowiedzialnej za ruchy w stawach biodrowych podczas każdej próby testu SOT. Im większa jest wartość MS tym większa jest aktywność mięśniowa odpowiedzialna za ruchy w stawach skokowych w porównaniu do aktywności mięśniowej odpowiedzialnej za ruchy w stawach biodrowych. Im mniejsza wartość MS tym większa aktywność mięśniowa odpowiedzialna za ruchy w stawach biodrowych w porównaniu do aktywności mięśniowej odpowiedzialnej za ruchy w stawach skokowych. Analiza strategii motorycznej umożliwia więc ocenę procentowego udziału aktywności mięśniowej odpowiedzialnej za ruchy w stawach skokowych i biodrowych w odpowiedzi posturalnej w określonych warunkach stymulacji sensorycznej (NeuroCom Int., 2008).

Analiza statystyczna przeprowadzona została przy użyciu programu STATISTICA 10 (StatSoft). Współzależność zmiennych określono na podstawie testu korelacji Pearsona, a w przypadku zmiennych, których rozkład nie był rozkładem normalnym - testem korelacji R Spearmana. Za istotne statystycznie zmiany przyjmowano te, w których poziom istotności $\mathrm{p}<0,05$.

\section{Wyniki}

W wyniku przeprowadzonych badań stwierdzono ujemną korelację wskaźnika BMI badanych kobiet $\mathrm{z}$ wynikami analizy równowagi ES oraz całkowitym wynikiem analizy równowagi CES (Ryc. 1).

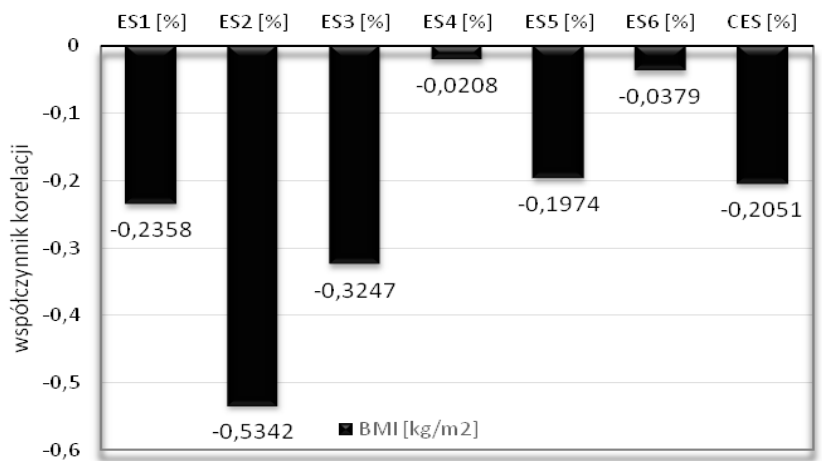

Rycina 1. Zależność pomiędzy wynikami analizy równowagi ciała (ES) w teście organizacji zmysłowej w warunkach SOT1-SOT6 oraz całkowitym wynikiem analizy równowagi ciała (CES) a wskaźnikiem BMI kobiet w okresie wczesnej starości

Źródło: opracowanie własne.

Wraz ze wzrostem wskaźnika BMI wartości wyników równowagi ES i CES przyjmowały mniejsze 
wartości, co świadczy o większych wychyleniach środka ciężkości ciała w kierunku przednio-tylnym we wszystkich warunkach testu SOT.

Zależności pomiędzy wynikami analizy sensorycznej oceniającymi sprawność poszczególnych układów sensorycznych i ich użyteczność w kontroli równowagi ciała a wskaźnikiem BMI przedstawiono na ryc. 2.

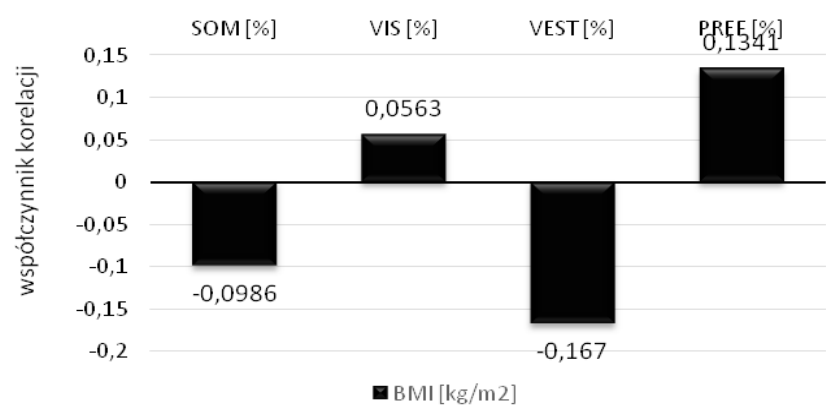

Rycina 2. Zależność pomiędzy wynikami analizy sensorycznej: ukadu somatosensorycznego (SOM), narządu wzroku (VIS), narządu przedsionkowego (VEST), preferencji wzrokowej (PREF) w teście organizacji zmysłowej (SOT) a wskaźnikiem BMI kobiet w okresie wczesnej starości Źródło: opracowanie własne.

Zależność pomiędzy wynikami analizy strategii motorycznej (MS) określne w teście organizacji zmysłowej (SOT) a wskaźnikiem BMI kobiet w okresie wczesnej starości przedstawiono na ryc. 3.

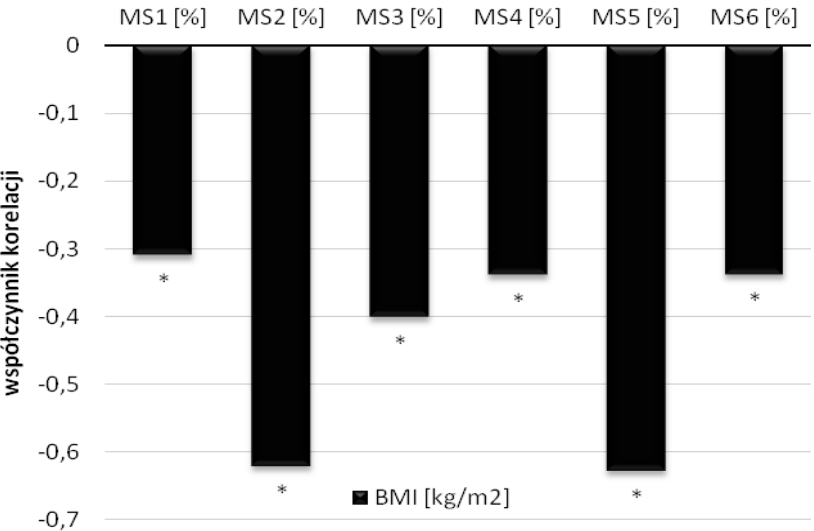

Rycina 3. Zależność pomiędzy wynikami analizy strategii motorycznej (MS) a wskaźnikiem BMI kobiet w okresie wczesnej starości

Źródło: opracowanie własne.

Pomiędzy wynikami strategii motorycznej a wartością wskaźnika BMI stwierdzono ujemną korelację. Wraz ze zwiększaniem się BMI ciała badanych kobiet wartości wyników analizy strategii motorycznej MS przyjmowały mniejsze wartości, co świadczy o przewadze aktywności mięśni odpowiedzialnych za ruch w stawach biodrowych. Wyniki analizy strategii motorycznej zależały znamiennie statystycznie od BMI osób badanych we wszystkich warunkach testu organizacji zmysłowej.

\section{Dyskusja}

Kontrola pionowej postawy ciała człowieka odbywa się poza jego świadomością i dopiero zaburzenie jej funkcjonowania uświadamia jak ważną rolę odgrywa ona w codziennym życiu. Ze względu na złożoną naturę działania układu kontroli równowagi ciała, istniej bardzo wiele czynników mogących mieć wpływ na prawidłowość jego funkcjonowania. Niestabilność posturalna spowodowana może być upośledzeniem któregokolwiek z komponentów biorących udział w kontroli równowagi ciała, lecz jedną z najczęściej wymienianych w literaturze przyczyn jej pogorszenia jest wiek człowieka (Borzym, 2009; Janczewski, Pierchała,2003).

Analiza wpływu wartości wskaźnika masy ciała (BMI) przeprowadzona została w grupie 41 kobiet po 60-tym roku życia wyłonionej z grupy 72 osób. Należy podkreślić , że tylko $57 \%$ osób ze wstępnej grupy nie wykazywało objawów klinicznych ze strony układu równowagi i nie było obciążonych czynnikami mogacymi upośledzać stabilność posturalną człowieka. $43 \%$ kobiet wykluczono z badań posturograficznych ze względu na przebyte urazy i towarzyszace im schorzenia lub choroby mogące upośledzać stabilność układ równowagi człowieka. Badania przeprowadzono w grupie osób o wskaźniku BMI >25kg/m². BMI pomiędzy 25-29,9 $\mathrm{kg} / \mathrm{m}^{2}$ uważany jest za nadwagę, podczas gdy wartość powyżej $30 \mathrm{~kg} / \mathrm{m}^{2}$ określa się mianem otyłości (Poskitt, 1995).

Przeprowadzone badania posturograficzne wykazały istotne statystycznie zależności $(p<0.05)$ pomiędzy wartością wskaźnika BMI i większymi wychwianiami ciała w kierunku przednio - tylnym ocenianymi podczas testu organizacji zmysłowej w warunkach prawidłowych sygnałów somatosensorycznych i przy baraku (SOT2) oraz nieprawidłowych sygnałach wzrokowych (SOT3) (rys.1). Fakt pogorszonej stabilności związany z nadwagą może być spowodowany nadmiernym otłuszczeniem i niemożnością wygenerowania odpowiedniej siły mięśniowej wymaganej do właściwego kontrolowania przemieszczeń środka ciężkości ciała.

Wartości wskaźnika BMI osób badanych korelowały znamiennie statystycznie $(p<0,05)$ z preferencją strategii posturalnej $\mathrm{w}$ każdej z prób testu SOT (rys.3). Zwiększone wartości tych parametrów wskazują, że seniorki chętniej wykorzystuja strategię stawu biodrowego, nie zawsze prawidłowo dobierając ją do wielkości zaburzeń stabilności ciała. Korelację wskaźnika masy ciała z parametrami posturalnymi zauważyli również Greve i in. (2007) oraz Helal i El Fiky (2015). Wyniki ich badań potwierdzają wpływ otyłości na preferencję strategii stawu biodrowego $\mathrm{w}$ kontroli równowagi ciała. Analizując stabilność w grupie otyłych osób autorzy pracy (Bučková i in., 2014) zaobserwowali znacznie ograniczone granice stabilności w kierunku przednio -tylnym i znacznie wolniejszą prędkość przemieszczenia środka ciężkości ciała $\mathrm{w}$ porównaniu do 
grupy kontrolnej podczas próby maksymalnego pochylenia do przodu. Różnice w strategii pochylenia ciała w obu grupach potwierdzają wyniki niniejszej pracy - u osób otyłych przeważało zgięcie samego tułowia, czyli strategia stawu biodrowego. Autorzy pracy (Vincent, Vincent, Lamb, 2010) również wskazują na większe ryzyko upadku w grupie otyłych kobiet. W ich opinii BMI i obwód talii są najlepszymi wskaźnikami ryzyka pogorszonej sprawności fizycznej, a kuracja odchudzająca może znacznie to ryzyko obniżyć. Błaszczyk i in. (2009) pogorszoną stabilność posturalną osób otyłych (BMI>40 kg/ $\mathrm{m}^{2}$ ), tłumaczą większą bezwładnością poszczególnych części ciała i relatywnym osłabieniem siły mięśniowej. Nieco wolniejsza reakcja i mniejszy zakres granic stabilności w kierunku przednio-tylnym według autorów spowodowane mogą być ograniczoną ruchomością lub sztywnością stawów. W pracy (Hue i in., 2007) jako przyczynę deterioracji stanu funkcjonowania układu równowagi w przypadku osób otyłych wskazano na większą powierzchnię przylegania stóp do podłoża, co z kolei zaburza sygnały odbierane przez mechanoreceptory podeszwowe stóp. Odmienne (gorsze) wykorzystanie informacji somatosensorycznych związane $\mathrm{z}$ większym naciskiem stóp na podłoże w przypadku nadmiernej masy ciała potwierdzają również wyniki tej pracy (rys.2). Wskutek gorszego wykorzystania informacji docierających do układu czucia głębokiego, osoby otyłe w większym stopniu niż osoby z normalną masą ciała polegają na informacjach wzrokowych, co potwierdzą dodatnie korelacje pomiędzy wynikami analizy sensorycznej narządu wzroku (VIS) i preferencji wzrokowej (PREF) a wskaźnikiem BMI badanych kobiet. Przez to złe warunki oświetleniowe lub całkowita ciemność wpływają bardzo destabilizująco na osoby otyłe.

Zmiany w posturze osób z nadwagą i osób otyłych związane są $\mathrm{z}$ różnym rozłożeniem tkanki tłuszczowej ciała i powodują przesunięcie środka masy ciała ku górze i przodowi w przypadku otyłości brzusznej, w przeciwieństwie do obniżającej jego położenie otyłości pośladkowo-udowej, która charakteryzuje głównie kobiety. Autorzy pracy (Hita-Contreras i in., 2013) uważają, że BMI>30kg/ $\mathrm{m}^{2}$ i typ otyłości mogą być dwoma niezależnymi wskaźnikami ryzyka upadków.

Obecnie odnotowuje się coraz większą rzeszę ludzi z nadwagą i ludzi otyłych. Mimo licznych badań nie poznano do tej pory ostatecznie jakie mechanizmy molekularne sprzyjają występowaniu nadwagi. Wyniki badań genetycznych uwarunkowań otyłości dają nadzieję na przyszłość. Być może wiedza ta pozwoli w niedalekiej przyszłości na stworzenie nowych leków, które będą u określonych osób leczyły otyłość i tym samym zapobiegały występowaniu wielu jej groźnych powikłaniom. Tymczasem, aby uchronić się przed przykrymi w skutkach powikłaniami nieleczonej nadwagi, należy zwrócić szczególną uwage na konieczność stosowania prawidłowej, zbilansowanej diety, unikania sytuacji sprzyjających tyciu, jak i propagowania aktywnego trybu życia. Nadwaga i otyłość wśród osób starszych pociąga za sobą szereg konsekwencji zdrowotnych i jest przyczyną nadciśnienia tętniczego, udarów, miażdżycy naczyń, cukrzycy typu 2, chorób układu kostno-stawowego, bólu kręgosłupa, zaburzeń emocjonalnych (niska samoocena), przerostu lewej komory serca, ogranicza tolerancję wysiłku (Gawlik i in., 2009; Haslam, James, 2005).

Wyniki tej pracy wskazują, że nadwaga może być przyczyną niestabilności posturalnej osób starszych i przez to prowadzić do częstszych upadków, ograniczeń w ich funkcjonowaniu fizycznym, emocjonalnym, społecznym i zawodowym i w konsekwencji do obniżenia jakości życia i skrócenie jego długości.

\section{Wnioski}

Uzyskane w pracy wyniki badań wskazują na:

1. Zwiększenie zakresu wychwiań środka ciężkości kobiet w okresie wczesnej starości w kierunku przednio - tylnym wraz ze wzrastającą wartością wskaźnika BMI.

2. Gorsze wykorzystanie informacji somatosensorycznych związane $\mathrm{z}$ większym naciskiem stóp na podłoże w przypadku nadmiernej masy ciała. Wskutek gorszego wykorzystania informacji docierających do układu czucia głębokiego, osoby otyłe w większym stopniu niż osoby z normalną masą ciała polegają na informacjach wzrokowych.

3. Wartość wskaźnika BMI badanych kobiet korelowała znamiennie statystycznie z preferencją strategii posturalnej. Osoby starsze wraz ze wzrastającą nadwagą chętniej wykorzystują strategię stawu biodrowego, nie zawsze prawidłowo dobierając ją do wielkości zaburzeń stabilności ciała.

Otrzymane ilościowe zależności pomiędzy parametrami układu równowagi ciała ocenianymi w badaniu komputerowej dynamicznej posturografii a wskaźnikiem BMI wskazują na niekorzystny wpływ nadwagi i otyłości na stabilność posturalną kobiet w okresie wczesnej starości.

\section{Literatura:}

1. Błaszczyk, J. (2004). Biomechanika Kliniczna: podręcznik dla studentów medycyny i fizjoterapii. Warszawa: Wydawnictwo Lekarskie PZWL.

2. Błaszczyk, J., Cieślinska-Swider J., Plewa M., Zahorska-Markiewicz B., Markiewicz A. (2009). Effects of Excessive Body Weight on Postural Control. Journal of Biomechanics, 42(9): 1295-1300. https://doi.org/10.1016/j.jbiomech.2009.03.006 
3. Błaszczyk J., Czerwosz L. (2005). Stabilność posturalna w procesie starzenia. Gerentologia Polska, 13(1), 25-36.

4. Błaszczyk, J., Lowe, D., Hansen, P. (1994). Ranges of postural stability and their changes in the elderly. Gait \& Posture, 2(1), 11-17. https://doi.org/10.1016/0966-6362(94)90012-4

5. Borzyn, A. (2009). Upadki osób w podeszłym wieku - przyczyny, konsekwencje i zapobieganie. Psychogeriatria Polska, 2, 81-88.

6. Bučková K., Lobotková J., Hirjaková Z., Bzdúšková D., Hlavačka F. (2014). Postural control assessed by limit of stability in obese adults. Act Nerv Super Rediviva, 56(3-4), 87-90.

7. Gawlik, A., Zachurzok-Buczyńska, A., Małecka-Tendera, E. (2009). Powikłania otyłości u dzieci i młodzieży. Endokrynol Otył Zab Przem Mat., 5(1), 19-27.

8. Edbom-Kolarz, A., Marcinkowski, J.T. (2011). Upadki osób starszych - przyczyny, następstwa, profilaktyka. Hygeia Public Health, 46(3), 313-318.

9. Greve, J., Alonso, A., Bordini, A.C., Camanho, G.L. (2007). Correlation between Body Mass Index and Postural Balance. Clinics (São Paulo, Brazil), 62(6), 717-720.

https://doi.org/10.1590/S1807-59322007000600010

10. Haslam, D.W., James, W.P. (2005). Obesity. Lancet. 366, 1197-1209. https://doi.org/10.1016/S0140-6736(05)67483-1

11. Helal, O.F., El Fiky, A.R. (2015). Early Adult Detection is a Good Protector from Balance Disturbance in Elderly. Journal of Physical Therapy and Health Promotion Dec, 3(4), 47-51. https://doi.org/10.18005/PTHP0304001

12. Held-Ziółkowska, M. (2006a). Organizacja zmysłowa i biomechanika układu równowagi. Magazyn Otorynolaryngologiczny, 5(2), 47-52.

13. Held-Ziółkowska, M. (2006b). Metody oceny równowagi posturalnej - komputerowa dynamiczna posturografia. Magazyn Otorynolaryngologiczny, 5(2), 53-57.

14. Hita-Contreras, F., Martínez-Amat, A., Lomas-Vega, R., Álvarez, P., Mendoza, N., Romero-Franco, N., Aránega, A. (2013). Relationship of Body Mass Index and Body Fat Distribution with Postural Balance and Risk of Falls in Spanish Postmenopausal Women. Menopause (New York, N.Y.), 20(2), 202-208 https://doi.org/10.1097/gme.0b013e318261f242

15. Horak, F.B. (2006). Postural Orientation and Equilibrium: What Do We Need to Know about Neural Control of Balance to Prevent Falls? Age and Ageing, 35(Suppl 2), ii7-ii11. https://doi.org/10.1093/ageing/afl077

16. Hue, O., Simoneau, M., Marcotte, J., Berrigan, F., Doré, J., Marceau, P., Marceau, S., Tremblay, A., Teasdale, N. (2007). Body Weight is a Strong Predictor of Postural Stability. Gait \& Posture, 26(1), 32-38. https://doi.org/10.1016/j.gaitpost.2006.07.005

17. Janczewski, G., Pierchała, K. (2003). Zaburzenia równowagi w wieku podeszłym. Przewodnik Lekarza, $6(2), 34-38$.

18. Janssen I. (2010). Evolution of Sarcopenia Research. Applied Physiology, Nutrition, and Metabolism = Physiologie Appliquee, Nutrition Et Metabolisme, 35(5), 707-712. https://doi.org/10.1139/H10-067

19. NeuroCom International (2008). Clinical Interpretation Guide. Pobrane z: http://balanceandmobility. academy/download/neurocom-clinical-operations-guide/

20. Olchowik, G., Tomaszewski, M., Olejarz, P., Warchoł, J., Różaska-Boczula, M., Maciejewski, R. (2015). The Human Balance System and Gender. Acta of Bioengineering and Biomechanics, 16(94), 69-74. https://doi.org/10.5277/ABB-00002-2014-05

21. Olejarz, P., Olchowik, G. (2011). Rola dynamicznej posturografii komputerowej w diagnostyce zaburzeń równowagi. Otorynolaryngologia, 10(3), 103-110.

22. Poskit, E. (1995). Defining childhood obesity: the relative body mass index (BMI). Acta Paediatr., 84, 961-962.

23. Vincent H.K., Vincent K.R., Lamb K.M., (2010). Obesity and Mobility Disability in the Older Adult. Obesity Reviews: An Official Journal of the International Association for the Study of Obesity, 11(8), 568-579. https://doi.org/10.1111/j.1467-789X.2009.00703

24. Wiszomirska I., Kaczmarczyk K., Zdrodowska A., Błażkiewicz M., Ilnicka L., Marciniak T., (2013). Evaluation of static and dynamic postural stability in young, elderly and with vision loss women. Advances in Rehabilitation, 27(3), 29-35. https://doi.org/10.2478/rehab-2014-0019 